\title{
“Socializing Economics:” Using Practical Applications to Enliven Economic Theory
}

Jean Kufrin Rosales

Wayne Journell

University of North Carolina at Greensboro

Economics has traditionally been taught in a way that emphasizes the "science" side of social science. This article suggests ways to cover the concepts introduced in high school economics using discussions, simulations, and discovery-based techniques that bring the "social" back into social science. Through descriptions of five authentic economic scenarios, the authors provide examples of ways in which teachers can help their students become engaged with economic concepts without using traditional methods that students often find dull or difficult to understand. Keywords: economics, economic theory, secondary education, economic instruction, teaching, curriculum

\section{Introduction}

Although economists may disagree on what concepts are considered to be the most important within their field, there seems to be general consensus within the profession that the purpose of economics education is to teach students to "think like an economist." Economists do have an unusual method of approaching problem-solving, and the analytical tools they have developed can be a valuable contribution to a student's intellectual toolkit. However, as Steven Miller and Phillip VanFossen (2008) note in their review of the literature on pre-collegiate economic education, relatively little is known about how middle and high school economics teachers broach economic theory in their classrooms.

Data, moreover, suggest that traditional methods of teaching economics have been somewhat unsuccessful in communicating the theoretical underpinnings of the field in such a way that students learn to think like economists. J. R. Clark and William Davis (1992) found that $42 \%$ of the students who took the 1986 Test of Economic Literacy (TEL) - developed and administered by the Joint Council on Economic Education (now the National Council on Economic Education) - scored no better or lower on the post-test than on the pre-test. Similarly, the first-ever test of economics included in the 2006 National Assessment of Educational Progress showed that $79 \%$ of senior high school students had an understanding of at least the basics of economics, but less than half (42\%) performed at a level deemed proficient.

In an analysis of the TEL test, William Walsted and Ken Rebeck (2001) found that high school students who had never taken an economics course were able to answer only $41 \%$ of the TEL questions correctly, while students who had taken an economics course scored $61 \%$ correct. 


\section{Social Studies Research and Practice \\ www.socstrp.org}

This finding is encouraging in the sense that it suggests students who have studied economics know more about the subject than those who have never studied it, but it is a bit dismaying to find that, had this been an exam based on a traditional grading scale, those students would have failed the test. Students who had taken an Advanced Placement (AP) economics course performed better than those who had taken the regular economics courses or no economics at all, but still only answered $74 \%$ of the questions correctly.

In 1990, George Vredeveld and Jin-Ho Jeong looked at the extent to which students and teachers agreed on the purpose of high school economics courses. They identified three possible goals:

- to better understand the American economy.

- to better understand current economics problems such as inflation and unemployment.

- to learn practical skills needed in daily life, such as balancing a checkbook, filling out tax forms, using credit cards, shopping wisely, and so on. (p. 319).

The teachers overwhelmingly felt the most important goal was understanding the American economy with $86 \%$ selecting that option. In contrast, only $39 \%$ of the students thought this was important. Yet, 54\% of the students and nearly 50\% of the teachers thought the practical skills goal was very important. While it only constitutes a bare majority of students' preferred goal, the practical skills goal was more popular to the students than both the "understand the American economy" and "understand economic problems" goals (39\% and 38\%, respectively) offered as purposes of their economic education. Since students do not seem to agree with their teachers on what is important, it's not surprising that Clark and Davis (1992) found that students were less enthusiastic about economics after they took their first economics class than they had been beforehand. Vredeveld and Jeong also found that students were less likely to say they liked economics and less likely to say they would take another economics course in the future when their teachers put a higher value on a particular goal of economics than they did. In particular:

Our findings that the skills goal was the most popular for students and the least popular for teachers imply that students would be less likely than teachers to anticipate the practical value of theory. Accordingly, when a teacher appropriately applied theory, the students feel good about the course because it meets their desire for something practical (Vredeveld and Jeong, 1990, p. 332).

The students in Vredeveld and Jeong's study were interested in the practical applications of economics-related topics. They were less interested in understanding economic issues and problems, and least interested in studying the theory of how the American economy works. Based on their study, one can infer that students like to see how what they are learning applies to skills and tasks they encounter in their own lives, which Stephen Thornton (2005) argues is essential to all aspects of social studies education.

Unfortunately for those practical-minded students, the trend in economics research in the United States, particularly since World War II, has become increasingly theoretical and abstract. Economics, as it is currently taught in American universities, tends to emphasize the need for formal modeling with an increasing emphasis on its mathematical underpinnings -- the "science" end of social science -- at the cost of the interest and understanding of those who are attracted to the social considerations of how people make decisions about spending, saving, working, 


\section{Social Studies Research and Practice \\ www.socstrp.org}

investing, and generally engaging in "social" behavior. Even though the science end of economics does ultimately have practical applications to social behavior and "real world problems," those applications do not usually take center stage in a typical introductory principles course and sometimes get lost in the mass of equations and graphs that are deemed essential to explaining economic behavior.

The body of research suggests there may be a disconnect between what students are interested in learning and how high school economics teachers think they should be teaching. To the extent that social studies teachers are more interested in the science than the social aspect of economics, they are less likely to create the type of practical and authentic types of economic exercises research has shown students appreciate in their economics classes. State social studies standards also contribute to this traditional approach to economics instruction as mandated economic content tends to value the "scientific" element of the discipline (VanFossen, 2006).

How can high school economics teachers, who are confronted with the task of teaching a subject students tend to dislike and frequently find has no real "application" or relevance to their lives, alter their instruction so that students are more engaged and begin to critically evaluate economic concepts? One course of action is to change, not the substance of what is being taught, but the way in which it is presented and applied such that the application and relevance of the material is made more obvious to students. The rest of this article discusses ways teachers can emphasize the social aspect of economic theory.

\section{Putting the "Social" Back in Social Science}

Based on the existing literature on economic education, there seems to be two ways to increase students' enthusiasm for and interest in economics: (1) introduce more situations and problems which students generally confront in their own lives and (2) encourage students to develop the theories themselves. The first suggestion addresses the issue of relevance and applicability. Using examples that arise in most people's lives makes the examples more interesting and might pique students' interest enough to cause them to remember what has been said.

The second suggestion, student-generated theories of behavior, provides students with an opportunity to "do" economics and to think like economists. Economics teachers frequently cover principles with the "chalk-and-talk" pedagogy of introducing a concept, demonstrating how that concept can be translated into either a graph or an equation (or both). There exist articles in economics education literature that recommend teachers use problem sets or realworld applications to illustrate and reinforce principles, but these articles often implicitly advocate introducing the applications after the definition, equations, and graphing have been introduced. (See, for example, Caviglia-Harris, 2003; Graves et al., 1996; Joerding, 2010; Krueger, 2001; Williams, 1997.)

A different approach reverses this process and lets students try to discover for themselves what the underlying principle(s) of behavior might be. In other words, teachers can present students with a scenario in which an economic concept is illustrated without explaining what that concept is, point them in the right direction, and see what they invent by themselves. In short, this approach makes greater use of "inquiry" or "discovery-based" learning in economics. It will probably be necessary to prompt students with good questions, but they frequently will be able to identify for themselves the relevant elements of the principle. Then, and only then -- when they have found the right pieces themselves -- can their theory be compared to the relevant principle 


\section{Social Studies Research and Practice \\ www.socstrp.org}

of economics and used as a springboard for showing how both the graphs and equations provide economists with a tool for discovering more about the phenomenon in question and uncovering other predictions of behavior they might not have otherwise found.

In the remainder of this section, we offer five authentic economic scenarios that can be used to get students critically thinking about basic economic concepts. These scenarios certainly do not encompass all of the ways in which teachers can promote economic thinking in their classes; rather, they are intended to be a guide for practicing and pre-service social studies teachers who wish to use this type of approach in their classes.

\section{Example 1: The Question of the Second Cup of Coffee}

In the 1980s, when the first author was a student at the University of Illinois, there was a coffee shop called the Daily Grind in Urbana that catered to the college crowd. They had a pricing scheme that was somewhat unusual for the time. Customers were charged $\$ 1.50$ for the first cup of coffee purchased, but only 50 cents for additional cups. One afternoon, my roommate and I started speculating on why a business would voluntarily reduce its revenue on sales like that. We came up with two possible explanations: one addressing the supply side, the other the demand side.

On the supply side, we hypothesized that the majority of the cost of producing a cup of coffee was fixed: the cost of providing a clean cup and spoon, paying rent, taxes, utilities, advertising, and the like. The cost of the actual coffee (along with the requisite cream, sugar, and sugar substitutes) is the variable cost the Daily Grind incurs every time it sells another cup of coffee. From the perspective of the owners, the Daily Grind had already incurred and paid for the fixed cost when the customer purchased that first cup, so they could afford to charge only the variable cost incurred for subsequent cups. In short, the 50-cent refill price reflected the marginal cost of extra cups of coffee, and the owners apparently were willing to accept that as reduced but still positive revenue.

On the demand side, we argued that the consumer's personal demand for that first cup of coffee (with its needed jolt of caffeine) was higher than $\$ 1.50$, so the consumer was willing to pay at least that much to get that first, all-important cup. However, once he or she had reestablished his or her caffeine equilibrium, the need for all subsequent cups was lower, so the original price was now potentially too high relative to the customer's personal valuation. If the Daily Grind wanted to sell the customer more cups of coffee, it would have to adjust pricing to meet the diminishing marginal utility to the customer. Being extraordinarily perceptive entrepreneurs, they did just that, dropping the price of refills to a point that would probably fall below the internal price the consumer placed on refills that had lower, but still positive, utility.

Whether or not my roommate and I were right about the actual decision-making processes of the owners of the Daily Grind is irrelevant. The point is that we "thought like economists" to analyze a situation we encountered most days when our need for caffeine and companionship caused us to visit the Daily Grind. It is interesting to note how many of the principles that are considered key in microeconomic theory show up in this explanation. We addressed supply, demand, fixed versus variable costs, revenue, utility, and the ever-important law of diminishing marginal returns, and we did it without once referring to algebra, calculus, or equations.

I have subsequently given this scenario to students and was pleasantly surprised to find they did a good job of recognizing the important elements of the solutions and that they could 


\section{Social Studies Research and Practice \\ www.socstrp.org}

see for themselves how the decisions of the coffee-drinking customer and the coffee-selling business owner were both decisions made at the margin. Decisions made at the margin tend to be one of the hardest concepts for novice economics students to grasp. Framing the discussion in terms of "what affects the decision about the second cup of coffee?" brought the concept home and made it easier to understand, even when we gave it that awkward but professionally correct name "marginality."

There are plenty of parallel situations that touch on the same idea. Why does McDonald's give away free refills on soft drinks? (They didn't always.) Why do many clothing and shoe retailers offer "buy one, get the second for X dollars off"? Most people will eventually hit on the idea that the second unit is worth less to the consumer, but often less expensive for the seller, so it is possible to generate an additional sale that is both satisfying to the buyer and profitable to seller by adjusting the price slightly.

\section{Example 2: The Trading Game}

The trading game starts with students working in four teams representing countries. Each country is given an allocation of total work hours than can be used to produce goods. There are four goods the country can produce, and workers in that country will produce different quantities of a good in a given period of time. That is, workers might be able to produce four units of food, but only two units of health care with one hour of work. Each country also faces two different domestic budgets, (1) the amount of each of the four goods the country must have to survive (the subsistence or "minimum" budget) and (2) the maximum amount of each of the four goods the country would be willing to consume if they had unlimited time and resources (the "maximum" budget).

In the first round, teams have to decide what they could produce, given their production possibilities, and what they will produce, given their domestic demands. As long as they stay within their production possibilities curve and stay with the limits of their minimum and maximum budgets, the teams are deemed to have succeeded in this round. Note that it isn't necessary (or even desirable) to use that language, but the concepts should be explained so students understand the rules.

In the second round, the teams again have to decide which goods to produce and what quantities to produce, but they are now allowed to trade with each other to fill their budgets. Although the teams do not know this at first, each has an absolute advantage in producing one of the four goods. Once they begin discussing their output with the other teams, they should find that it would be beneficial to both countries to specialize and then trade their surplus production. The results of trading usually will demonstrate that every country was able to produce and consume more after trading than they did when they produced everything domestically.

The game can be expanded with extra rounds that change some of the underlying assumptions. The aggregate domestic consumption budgets, for example, can be set up in such a way that international demand for one good is less than the total amount of the good that can be produced by the country specializing in that product. This unfortunate country will have to either switch to producing a second good with the surplus labor they have available or end up with unemployment and fewer goods than they might have had.

It is also possible to create a shortage of a good that has high demand and see if students decide to produce it domestically if the world market price gets too high or try to find the second most efficient producer of that good to continue trading. Countries can be permitted to engage in 


\section{Social Studies Research and Practice \\ www.socstrp.org}

bilateral negotiations in the first round, in which only the parties to a trade know what the ultimate terms of trade were, and have a second round in which the class works under Most Favored Nation rules, such that every country pays the same price for the good, which can be pegged as the lowest price negotiated in the bilateral rounds.

The trading game introduces a number of basic concepts of economics: production possibilities, absolute and relative advantage, limits of resources, satiation, specialization, and terms of trade. An important part of making this a good exercise for students is holding a debriefing session after each round and encouraging students to think back about their experiences in making trade decisions. They should recognize the concepts at work, even if they don't know the formal name for those ideas. With this hands-on background to work from, they will probably find chalk-and-talk discussion of the principles more relevant and understandable.

\section{Example 3: The Money on the Doorstep}

This discussion item comes from a lecture delivered by Harvard economist John Kenneth Galbraith at the University of Illinois in 1979. It illustrates the difference between real and nominal income; another concept students often have trouble understanding. Galbraith invited his audience to imagine being at home one night when the phone rings. An unidentified voice tells a lucky individual that he/she should look on the front doorstep at 6 a.m. tomorrow morning, where he/she will find an envelope with \$1000 cash.

The following morning, the individual finds there is, indeed, an envelope lying on the front doorstep with money, but it only contains $\$ 880$. Galbraith asked, "Do you feel happy that you now have $\$ 880$ you didn't have before? Or do you feel cheated because you were expecting to receive $\$ 1,000$ and only received $\$ 880$ ?" The missing money, he explains, is the result of a $12 \%$ rate of inflation. The individual was promised $\$ 1,000$ of nominal income, but inflation eroded away $\$ 120$ before the money arrived, leaving a real income of only $\$ 880$.

Galbraith suggested most people will feel cheated, because they feel they had earned the original sum and had the difference stolen away from them, but goes on to point out that raises in income are frequently simply adjustments to compensate for inflation, similar to the cost-ofliving adjustments usually applied to Social Security payments, government worker salaries, and the like. It's a sophisticated concept, but it does get students thinking about the effect of inflation on nominal incomes and whether or not a raise in salary actually leads to an increase in buying power.

The discussion can be expanded by bringing in the effects of differences in costs of living in salaries. The average salary of public school teachers in the District of Columbia in 20072008 was $\$ 60,000$. The average salary of public school teachers in North Carolina was $\$ 47,000$ (NEA, 2008). Are DC teachers $27 \%$ more valuable than North Carolina teachers? Maybe, but it is a lot more likely that the salary differences reflects the differences in costs of living. One source states that someone living on a $\$ 60,000$ salary in DC would only have to earn $\$ 41,000$ in Greensboro, North Carolina to maintain the same standard of living (City Rating, 2010). Surprisingly, with that adjustment made, it seems that North Carolina teachers are actually better paid than their DC counterparts.

\section{Example 4: Burgernomics}

Since 1970, the Economist has been collecting data on the price of Big Macs around the world and compiling their "Big Mac Index" as part of their theory of burgernomics, which estimates purchasing-power parity between nations (The Economist, 2010). Their reasoning is 


\section{Social Studies Research and Practice \\ www.socstrp.org}

that since Big Macs contain the same ingredients the world over, they should sell for the same price in each of the 120 countries surveyed. Observing that Big Macs don't, in fact, sell for the same price everywhere, they argue that the difference is attributable to the local country's currency being over- or under-valued relative to the American dollar.

In July 2009, the Big Mac sold for \$3.57 in the United States, \$6.15 in Norway, and $\$ 1.49$ in China. Since Big Macs are relatively expensive in Norway, the burgernomics suggests Norway's currency is over-valued. A Chinese Big Mac is pretty cheap compared to the American product, which indicates the Chinese currency is under-valued compared to the dollar.

It is a little easier to see these results via an index, rather than absolute prices. If we let the American Big Mac cost \$1, a Norwegian Big Mac would cost \$1.72 and a Chinese Big Mac would cost $\$ 0.51$. The question, of course, is why? The Economist argues the difference is an under- and over-valuation of the countries' currency in world markets. At this point, students should be invited to consider other contributing factors. Is it true that the costs of production for Big Macs are equal in all countries? Are labor conditions the same in China as they are in Norway? Are there tariffs and taxes or subsidies built into the cost of non-U.S. Big Macs that artificially raise or lower the price? If so, do those tell us anything about public policy goals in those countries? Is the Big Mac index just a fun way to look at prices or does it provide an accurate measure of currency valuation around the world? Are there any other popular goods that could serve as a popular index to currencies? What qualities would those goods need to have to be Big Mac equivalents?

\section{Example 5: The Midas Plague}

In 1954, science fiction writer Frederick Pohl (1973) published a short story entitled "The Midas Plague," which has the distinction of being one of the few pieces of fiction featuring a storyline and premise that are drawn directly from economic theory. Pohl's premise for his world of the future is that resources are abundant and consumers are super-satiated. As such, the sign of status, being wealthy, is being able to only consume what you feel like consuming. Those who are considered poor in this world have a quota of goods they are required to consume every month. As frequently happens inside and outside of science fiction, a clash in socioeconomic status and expectations arises from the marriage of a rich girl to a poor boy, causes marital strife and leads the hero to search for ways to spare his beloved from the burden of having to consume yet another diamond bracelet.

In this instance, it does help to have some familiarity with basic economic principles; in this case, the assumption that "resources are scarce, while wants are insatiable." Turning this assumption on its head creates some interesting questions about how to think like an economist when the economic problem is dissimilar to the ones we normally face.

Unlike the real-world situation most of us are familiar with, Pohl has made goods abundant, which would make it seem that there is no "economic problem" for this society. In fact, there is scarcity in Pohl's world. Various characters complain of not having enough time to do what they want to do since they have to spend so much time consuming, and the hero's wife complains of having lost her freedom of choice over what to consume. Economic theory generally assumes that physical and human capital are the resources that are scarce relative to demand; Pohl rightly points out that participants in an economy that has abundant resources might still experience a shortage of time and self-determination, resources with economic values that are usually not set in the marketplace but with consumption values that are clearly non-zero. 


\section{Social Studies Research and Practice \\ www.socstrp.org}

As the U.S. labor force has changed over time to include longer work weeks and twoearner families, the value of leisure time and control over one's environment and activities are becoming negotiating factors in job offers and acceptance. It is not uncommon to read news media surveys of working conditions in which workers say they would take a lower-paying job in order to spend more time with family or to be in a work environment that adapted to their lifestyle preferences. Pohl's story can serve as a starting point to discuss whether or not "the market" truly captures all costs and benefits of goods and how, if at all, firms adapt to compete for talented workers that value non-economic rewards.

Exercises that fit into this model of teaching let students assess a situation and discover economics principles for themselves. The key to modifying economic activities into these types of "think for yourself" exercises is resisting the temptation to give away the "cheat codes" at the beginning of the exercise. "Cheat codes" in video gaming are directions or activities that essentially provide the gamer with the solution he or she needs to complete the game or task. Cheat codes in economics tend to be the principles themselves; how to calculate absolute and relative advantage, comparing costs and benefits at the margin, and so on. While having access to cheat codes helps relieve frustration for students when they have run into a brick wall, it eliminates the opportunity for students to figure it out for themselves.

\section{Conclusion}

Writing in 2005, Alan Greenspan noted,

Twenty-five years ago, knowing how to maintain a checking and savings account at a local financial institution was sufficient for many Americans. Today's consumers, however, must be able to differentiate among a wide range of products, services, and providers of financial products in order to manage their personal finances successfully ( $\mathrm{p}$. 64).

Clearly, having a basic understanding of consumer finance and economic principles is more important now than ever before, but sadly, the economic instruction students receive in middle and high school is too often so abstract that students cannot make adequate connections between the theory being presented in class and the real-life economic decisions affecting their daily lives. In this article, we have argued that traditional methods of teaching economics do little to engage students and rarely provide the authentic context from which students can apply the concepts being taught.

The idea of using examples to illustrate elements of economic theory is not new. Adam Smith, his contemporaries, and his successors all routinely point to behavior observable in the real world to demonstrate for their readers the ideas they are exploring. The current contribution to this tradition is not so much the recognition that students benefit from having examples to help them make the connection between theory and reality, as that has been demonstrated in a variety of disciplines (e.g., Smith \& Stein, 1998); rather, it is that students benefit from being allowed to explore and analyze those examples on their own before they are given the textbook explanation for the concept at hand and taught graphic and mathematic presentations of those ideas.

Economics professors John Chizmar and Mark Walbert (1999) recommend that economics teachers learn to play the role of the "guide on the side," rather than the "sage on the stage" (p. 257). Incorporating games and scenarios in which students are encouraged to consider on their own why consumers and producers make certain decisions when they enter the marketplace helps bring back the relevance of economic theory and encourages students to 


\section{Social Studies Research and Practice \\ www.socstrp.org}

perceive "what economists do" as an interesting and useful way of looking at the world. This, in turn, helps them learn and remember the concepts long after the exams are passed.

\section{References}

Caviglia-Harris, J. L. (2003). Introducing undergraduates to economics in an interdisciplinary setting. The Journal of Economic Education, 34, 195-203.

Chizmar, J. F., \& Walbert, M. S. (1999). Web-based learning environments guided by principles of good teaching practice. Journal of Economic Education, 30, 248-259.

Clark, J. R., \& Davis, W. L. (1992). Does high school economics turn off too many students? Journal of Education for Business, 67, 152-155.

Graves, P. E., Sexton, R. L., \& Lee, D. R. (1997). Slope versus elasticity and the burden of taxation. The Journal of Economic Education, 27, 229-232.

Greenspan, A. (2005). The importance of financial education today. Social Education, 69, 64-65. Joerding, W. (2010). Teaching and learning with individually unique exercises. The Journal of Economic Education 41, 125-135.

Krueger, A. B. (2001). Teaching the minimum wage in Econ 101 in light of the new economics of the minimum wage. The Journal of Economic Education, 32, 234-258.

Miller, S. L., \& VanFossen, P. J. (2008). Recent research on the teaching and learning of precollegiate economics. In L. S. Levstik \& C. A. Tyson (Eds.), Handbook of research in social studies education (pp. 284-304). New York: Routledge.

Pohl, Frederick. (1973). The Midas Plague. In B. Bova (Ed.), Science Fiction Hall of Fame, Volume 2B (pp. 259-312). New York: Doubleday.

Smith, M. S., \& Stein, M. K. (1998). Selecting and creating mathematical tasks: From research to practice. Mathematics Teaching in the Middle School, 3, 344-350.

Thornton, S. (2005). Teaching social studies that matters: Curriculum for active learning. New York, NY: Teachers College Press.

VanFossen, P. (2006). Economic concepts at the heart of civic education. International Journal of Social Education, 20(2), 35-66.

Vredeveld, G. M., \& Jeong, J. (1990). Market efficiency and student-teacher goal agreement in the high school economics course: A simultaneous choice modeling approach. Journal of Economic Education, 31, 317-335.

Walsted, W., \& Rebeck, K. (2001). Assessing the economic understanding of U.S. high school students. The American Economic Review, 91, 452-457.

Williams, A. T. (1997). Estimating the cost to consumers of the U.S. sugar quota: An exercise for introductory economics classes. The Journal of Economic Education, 28, 173-181.

\section{Web Based References}

City Rating. (2010). Cost of living. Calculations in the text were made using the Web site calculator at http://www.cityrating.com/costofliving.asp.

National Center for Education Statistics. (2006). The Nation's Report Card: Economics 2006. National Assessment of Educational Progress at Grade 12. (NCES Publication No. NCES 2007-475.) Retrieved from National Center for Education Statistics: 
http://nces.ed.gov/nationsreportcard/economics/.

National Education Association. (2008). Average salaries of public school teachers, 2007-2008.

Retrieved from http://dcjobsource.com/teachersalaries.html.

The Big Mac index. (2010). The Economist. Retrieved from

http://www.economist.com/markets/bigmac/about.cfm.

\section{Author Bios}

Jean Kufrin Rosales has a Ph.D. in political science from the University of Texas at Austin. She is currently the graduate program administrator for the Department of Economics at the University of North Carolina at Greensboro. Her research and teaching interests include helping students apply economic thinking to real world situations.

Wayne Journell is an assistant professor and secondary social studies program coordinator at the University of North Carolina at Greensboro. E-mail: wayne_journell@uncg.edu 